\title{
ASEAN Intergovernmental Commission on Human Rights and Effectiveness of Fulfilling Human Rights Obligations of ASEAN Members States
}

\author{
Budi Hermawan Bangun \\ Faculty of Law, Universitas Tanjungpura \\ budi.h.bangun79@gmail.com
}

\begin{abstract}
The inauguration of the ASEAN Declaration of Human Rights was inseparable from criticism from several parties, especially human rights organizations both within and outside ASEAN member states. This paper focuses on the function and mandate of the AICHR (ASEAN Intergovernmental Commission on Human Rights) and its influence on the effectiveness of the fulfillment of human rights obligations ASEAN member states. The results showed that within its mandate AICHR there is no balance between the functions of promotion and protection function because of the ambiguity of vision for an ASEAN Human Rights set the standard, which is between universal standards and particularist that maintains the principle of "Asian values" and "non-interference". These different points of view led to the implementation of human rights obligations fulfillment by member states of ASEAN to be very varied
\end{abstract}

Keywords: functions and mandate, the AICHR, the state's obligation.

\section{A. Introduction}

ASEAN (Association of Southeast Asian Nations) has achieved new developments in the promotion and protection of human rights by 
agreeing to the establishment of an ASEAN Human Rights Body called the ASEAN Intergovernmental Commission on Human Rights (AICHR) in accordance with Article 14 of the ASEAN Charter. AICHR is an intergovernmental body consultative in the ASEAN organizational structure whose functions include providing advisory services and technical assistance for ASEAN sectoral bodies, and reporting all activities to the ASEAN Foreign Ministers Meeting.

AICHR then drafted an ASEAN Declaration of Human Rights approved at the 21st ASEAN Summit in Phnom Penh, Cambodia on November 18, 2012. The ASEAN Human Rights Declaration is not legally binding, however it is a very important basic instrument for the enforcement and protection of human rights in the Southeast Asia region.. ${ }^{1}$ The declaration is also expected to give birth to a number of conventions on human rights in ASEAN.

On the other hand, the inauguration of the ASEAN Declaration of Human Rights was inseparable from criticism from several parties, especially human rights organizations both within and outside ASEAN member states. The criticism concerns the standards of the ASEAN Declaration of Human Rights which is considered not in accordance with international human rights standards. ${ }^{2}$ Some provisions of the substance of the ASEAN Declaration of Human Rights which contain restrictions on human rights for reasons of public security, public morals and public order are considered to have no clear meaning and create a gap for abuse. Likewise with the existence of a sentence that says that human rights must be in accordance with the obligations deemed not in accordance with the principles of human rights itself.

Critics of the ASEAN Declaration of Human Rights have added to the list of concerns about how effective the ASEAN regional human rights system and mechanism is. This is related to "The ASEAN

1 AICHR and The ASEAN Human Rights Declaration are the fourth regional human rights system and mechanism after the Europe (1950), Inter-America (1969), and Africa (1981).

2 See Ronald Eberhard, “The ASEAN Approach to Human Rights", The Jakarta Post, December 6, 2012. 
Way" and there are very striking differences in the system of governance between ASEAN member states.

In this regard, this article will discuss the scope of the functions and mandates of AICHR as a human rights body at the Southeast Asian regional level and then continue with its influence on the effectiveness of fulfilling human rights obligations by ASEAN member states.

\section{B. The Scope of the Functions and Mandates of AICHR}

The Bangkok Declaration that established ASEAN in 1967 did not explicitly regulate the enforcement of human rights. Of the seven ASEAN objectives contained in the Bangkok Declaration, only the second objective can be linked to human rights, namely:

To promote regional peace and stability through abiding respect for justice and the rule of law in the relationship among countries of the region and adherence to the principles of the United Nations Charter

On November 20, 2007, in the 13th ASEAN Summit in Singapore, the ASEAN Charter was formed and officially effective since December 15, 2008. The ASEAN Charter can be said to be more comprehensive than the Bangkok Declaration because the ASEAN Charter consists of articles governing various problems in ASEAN. In the ASEAN Charter there are clauses which give new hope for the protection of human rights in ASEAN. These human rights issues include the Preamble, Purposes (Article 1 paragraph (7), and Principles (Article 2 paragraph (2) (i) and Article 14 which specifically regulate about human rights.

At the preamble of the ASEAN Charter that has been agreed upon, ASEAN member states are mandated to adhere to the respect and protection of human rights and fundamental freedoms. The statement is explicitly elaborated in the objectives and principles of ASEAN formation, namely Article 1 paragraph (7) and Article 2 paragraph (2) (i) that ASEAN is determined to advance protecting human rights in the ASEAN region. This principle implies that ASEAN must play a real role in maintaining the sustainability of the ASEAN region 
in providing human rights promotion and protection.

Human rights enforcement in ASEAN found a bright spot with Article 14 of the ASEAN Charter concerning the ASEAN human rights body that states: ${ }^{3}$

(1) In conformity with the purposes and principles of the ASEAN Charter relating to the promotion and protection of human rights and fundamental freedoms, ASEAN shall establish an ASEAN human rights body.

(2) This ASEAN human rights body shall operate in accordance with the terms of reference to be determined by the ASEAN Foreign Ministers Meeting.

Based on the clauses contained in the preamble, purposes, principles and Article 14, there are at least two functions and mandates that must be carried out by AICHR, namely promotion and protection functions. The function of promoting human rights is a function of the Human Rights Commission to disseminate and educate human rights through providing information and conducting human rights education; holding seminars, symposia, conferences, disseminating information to introduce human rights and towards national and local institutions; collect documents and conduct studies and research on human rights issues in ASEAN; formulate and establish principles and rules aimed at resolving legal issues related to human rights; cooperate with institutions both in ASEAN, Asia or international areas related to the dissemination and protection of human rights; periodically consider country reports on the law or actions taken by the state to provide protection for the rights and freedoms guaranteed in the ASEAN Charter.

Furthermore, the protection of human rights function means that the Human Rights Commission must be responsible for ensuring the protection of human rights in conditions stipulated in the Charter and according to the rules stipulated regarding the procedure. The implementation of Article 14 of the ASEAN Charter on the establishment of the ASEAN Human Rights Body was followed

3 See Art. 14 ASEAN Charter, 
up with the establishment of the AICHR on October 23, 2009.

AICHR has various functions in upholding human rights in ASEAN. Referring to the AICHR Term of Reference (ToR), the objectives of the establishment of the ASEAN Human Rights Commission are: ${ }^{4}$

1. Topromote and protect human rights and freedom of fundamental freedoms of the peoples of ASEAN;

2. To uphold the right of the peoples of ASEAN to live in peace, dignity and prosperity;

3. To contribute to the realization of the purposes of ASEAN as set out in the ASEAN Charter in order to promote stability and harmony in the region, friendship and cooperation among ASEAN Member States, as well as the well-being, livelihood, welfare and participation of ASEAN peoples in the ASEAN Community building process;

4. To promote human rights within the regional context, bearing in mind national and regional particularities and mutual respect for different historical, cultural and religious backgrounds, and taking into account the balance between rights and responsibilities;

5. To enhance regional cooperation with a view to complementing national and international efforts on the promotion and protection of human rights; and

6. To uphold international human rights standards as prescribed by the Universal Declaration of Human Rights, the Vienna Declaration and Programme of Action, and international human rights instruments to which ASEAN Member States are parties.

Referring to the fourth point of the AICHR ToR, the ASEAN Human Rights Commission has various functions in upholding human rights in ASEAN, including formulating efforts to promote and protect human rights in the ASEAN region through education, monitoring, dissemination of international human rights values and standards, encouraging ASEAN member countries to accept and ratify international human rights instruments, support the full implemen-

4 See Art. 1 ToR AICHR 
tation of ASEAN instruments related to human rights enforcement, provide consultation, dialogue and technical assistance services for every human rights issue in ASEAN by involving NGOs and other stakeholders and conducting research on human rights enforcement in ASEAN. ${ }^{5}$

From the objectives of the establishment of the AICHR, it can be seen that ASEAN member states still have doubts about human rights norms that are universally applicable throughout the world. This doubt appears with an emphasis on the need to consider the existing characteristics, history, culture and even religion in ASEAN which they later call the ASEAN values. These universally applicable human rights values or standards are still considered as a form of western cultural intervention (western) towards eastern cultural values that exist and develop in ASEAN. This certainly can be a stumbling block for AICHR in the promotion and protection of human rights work in ASEAN in the future.

The AICHR ToR also stipulates a number of principles that must be used as AICHR references in carrying out their duties. These principles are: ${ }^{6}$

1. Respect for principles of ASEAN as embodied in Article 2 of the ASEAN Charter, in particular:

a. respect for the independence, sovereignty, equality, territorial integrity and national identity of all ASEAN Member States;

b. non-interference in the internal affairs of ASEAN Member States;

c. respect for the right of every Member State to lead its national existence free from external interference, subversion and coercion;

d. adherence to the rule of law, good governance, the principles of democracy and constitutional government;

e. respect for fundamental freedoms, the promotion and

5 Inggrid Galuh Mustikawati, "Perjalanan Penegakan HAM di ASEAN dan Peran Indonesia Dalam Mendukung Keberlanjutan AICHR”, Jurnal Demokrasi dan HAM, Vol. 9, No. 1, 2011, pp. 20-21.

6 See Art. 2 ToR AICHR. 
protection of human rights, and the promotion of social justice;

f. upholding the Charter of the United Nations and international law, including international humanitarian law, subscribed to by ASEAN Member States; and

g. respect for different cultures, languages and religions of the peoples of ASEAN, while emphasising their common values in the spirit of unity in diversity.

2. Respect for international human rights principles, including universality, indivisibility, interdependence and interrelatedness of all human rights and fundamental freedoms, as well as impartiality, objectivity, non-selectivity, non-discrimination, and avoidance of double standards and politicisation;

3. Recognition that the primary responsibility to promote and protect human rights and fundamental freedoms rests with each Member State;

4. Pursuance of a constructive and non-confrontational approach and cooperation to enhance promotion and protection of human rights; and

5. Adoption of an evolutionary approach that would contribute to the development of human rights norms and standards in ASEAN.

The inclusion of the above clauses opens up a large space for political intervention from the Governments of ASEAN Member States, given the role of the AICHR is only a 'consultative body'.? In particular, the emphasis given to the principle of non-intervention shows that the resolution of human rights violations that occur in the territory of ASEAN member countries is left to each country and thus, cannot be appointed as a regional problem. The idea to review the application of the principle of non-intervention was actually initiated by the former Secretary General of ASEAN, Surin Pitsuwan. ${ }^{8}$

7 See Art. 3. ToR AICHR. This article contains ambiguous interpretations. The AICHR consultative role can be facilitated that the AICHR must consult and base each of its decisions on consensus.

8 S. Sudo, “A Reinvigorated Version of Japan’s Comprehensive Security: Key 
From the basic principles that should be used as guidelines for the AICHR in carrying out its duties, it is clear that ASEAN member states do not want human rights issues to interfere with the running of the government in each ASEAN member states. Such as the principle of non-intervention, for example, it is clear that in the future if there are gross violations of human rights in ASEAN member states it will not be questionable or even processed by the AICHR, arguing that this is a form of intervention against the sovereignty of ASEAN member states.

However, the AICHR still recognizes international human rights standards as norm standards that must be respected by each ASEAN member states, where international human rights law allows intervention, even sanctions, to a country if gross human rights violations occur in it. This shows ASEAN's anxiety in addressing the development of human rights issues in the world, so that the basic principles set out in the AICHR ToR conflict with each other, including with basic human rights principles.

The situation above can be seen in Article 1.6 of the AICHR ToR stipulating the objectives of the AICHR are:

To uphold international human rights standards as prescribed by the Universal Declaration of Human Rights, the Vienna Declaration and Programme of Action, and international human rights instruments to which ASEAN Member States are parties.

In addition, respect for international human rights principles, including the universality of human rights, is also emphasized as one of the guiding principles for AICHR. However, Article 1.4 of the AICHR ToR emphasizes national and regional specificities and different historical, cultural and religious backgrounds in the implementation of human rights in ASEAN. ${ }^{9}$ If interpreted, this article undoubtedly confirms the concept of "Asian values" as a counter argument against the universality of human rights.

to Stability In The Asia Pacific”, in J.C. Hsiung (ed.), Twenty-First Century World Order and the Asia Pacific: Value, Change, Exigencies, and Power Realignment, Palgrave Macmillan, New York, 2001, p. 300.

9 See Art. 1.4. ToR AICHR. 
The same thing exist is granting mandate to the AICHR as stipulated in point 4 of the AICHR ToR. There are 14 mandates given by the ToR on AICHR, but none specifically regulates the function of protecting human rights. Not regulating the protection function in the AICHR ToR makes this institution unable to make efforts to prevent the occurrence of human rights violations in the region. Moreover, the human rights violations that have already occurred are impossible to process by the AICHR because investigations have been considered as a form of intervention. The lack of regulatory protection functions that should be owned by the AICHR makes it difficult for these institutions to take other preventive measures, such as encouraging ASEAN member states to synchronize their national legislation so that they are in harmony with universal human rights principles, or encourage openness to accept monitoring missions (monitoring) conducted by AICHR. ${ }^{10}$

The mandate and function of AICHR as contained in Article 4 of the AICHR ToR is: ${ }^{11}$

1. To develop strategies for the promotion and protection of human rights and fundamental freedoms to complement the building of the ASEAN Community;

2. To develop an ASEAN Human Rights Declaration with a view to establishing a framework for human rights cooperation through various ASEAN conventions and other instruments dealing with human rights;

3. To enhance public awareness of human rights among the peoples of ASEAN through education, research and dissemination of information;

4. To promote capacity building for the effective implementation of international human rights treaty obligations undertaken by ASEAN Member States;

5. To encourage ASEAN Member States to consider acceding to

10 See Kompas, "Badan HAM ASEAN Jauh di Bawah Standar”, at http:/ / internasional.kompas.com/ read/2009/08/09/06163052/badan.ham.asean. jauh.di.bawah.standar, accessed in October 30, 2018.

11 See Art. 4 ToR AICHR. 
and ratifying international human rights instruments;

6. To promote the full implementation of ASEAN instruments related to human rights;

7. To provide advisory services and technical assistance on human rights matters to ASEAN sectoral bodies upon request;

8. To engage in dialogue and consultation with other ASEAN bodies and entities associated with ASEAN, including civil society organizations and other stakeholders, as provided for in Chapter $\mathrm{V}$ of the ASEAN Charter;

9. To consult, as may be appropriate, with other national, regional and international institutions and entities concerned with the promotion and protection of human rights;

10. To obtain information from ASEAN Member States on the promotion and protection of human rights;

11. To develop common approaches and positions on human rights matters of interest to ASEAN;

12. To prepare studies on thematic issues of human rights in ASEAN;

13. To submit an annual report on its activities, or other reports if deemed necessary, to the ASEAN Foreign Ministers Meeting; and

14. To perform any other tasks as may be assigned to it by the ASEAN Foreign Ministers Meeting.

The mandate and function of the AICHR mentioned in the ToR above contains four main points, namely regarding standard settings, promotion and education, protection, and reporting.

From the mandates held by the AICHR, it is clear that there is an imbalance between the promotion function and the protection function provided by ASEAN to the AICHR to promote human rights in ASEAN. Whereas as stipulated in Article 14 paragraph (1) of the ASEAN Charter it is clearly stated that the purpose of the establishment of the ASEAN Human Rights Body is to ensure the functioning of the promotion and protection of human rights in the ASEAN region. The weak function of of human rights protection by the AICHR makes many people consider that the AICHR is a "toothless" 
Table: AICHR Mandate

\begin{tabular}{|c|c|c|c|}
\hline Standart Setting & $\begin{array}{l}\text { Promoting and Educa- } \\
\text { tion }\end{array}$ & Protecting & Reporting \\
\hline $\begin{array}{l}\text { Develop advance- } \\
\text { ment strategies } \\
\text { of human rights } \\
\text { protection and } \\
\text { fundamental free- } \\
\text { dom fto complete } \\
\text { ASEAN Commu- } \\
\text { nity formation }\end{array}$ & $\begin{array}{l}\text { Develop a ASEAN } \\
\text { Declaration of Human } \\
\text { Rights for creating hu- } \\
\text { man rights cooperation } \\
\text { framework through } \\
\text { various ASEAN conven- } \\
\text { tions and other instru- } \\
\text { ments related to human } \\
\text { rights. }\end{array}$ & $\begin{array}{l}\text { Get informa- } \\
\text { tion from ASE- } \\
\text { AN Member } \\
\text { States about } \\
\text { advancement } \\
\text { and protec- } \\
\text { tion of human } \\
\text { rights }\end{array}$ & $\begin{array}{l}\text { Submit an- } \\
\text { nual activ- } \\
\text { ity report or } \\
\text { other reports } \\
\text { if needed, on } \\
\text { the ASEAN } \\
\text { Foreign } \\
\text { Minister's } \\
\text { Meeting. }\end{array}$ \\
\hline $\begin{array}{l}\text { Advance enhance- } \\
\text { ment ability to ef- } \\
\text { fective implemen- } \\
\text { tation of human } \\
\text { rights agreement } \\
\text { obligation by } \\
\text { ASEAN Member } \\
\text { States. }\end{array}$ & $\begin{array}{l}\text { Upgrading public } \\
\text { awareness of human } \\
\text { rights among ASEAN } \\
\text { peoples through educa- } \\
\text { tion, research, and } \\
\text { information dissemina- } \\
\text { tion }\end{array}$ & $\begin{array}{l}\text { Preparing stud- } \\
\text { ies about the- } \\
\text { matic issues of } \\
\text { human rights } \\
\text { in ASEAN. }\end{array}$ & $\begin{array}{l}\text { Perform } \\
\text { other tasks } \\
\text { that might be } \\
\text { given by the } \\
\text { ASEAN For- } \\
\text { eign Minis- } \\
\text { ter's Meeting. }\end{array}$ \\
\hline $\begin{array}{l}\text { Encouraging } \\
\text { ASEAN Member } \\
\text { States to consider } \\
\text { to accede and } \\
\text { ratify internation- } \\
\text { al human rights } \\
\text { instruments. }\end{array}$ & $\begin{array}{l}\text { Giving consultation and } \\
\text { technical assistance re- } \\
\text { lating humans rights is- } \\
\text { sues to ASEAN sectoral } \\
\text { bodies on request. }\end{array}$ & & \\
\hline $\begin{array}{l}\text { Promoting the } \\
\text { fully implementa- } \\
\text { tion of ASEAN } \\
\text { instruments } \\
\text { related to human } \\
\text { rights }\end{array}$ & $\begin{array}{l}\text { Make dialogue and con- } \\
\text { sult with other ASEAN } \\
\text { bodies and other enti- } \\
\text { ties related to ASEAN, } \\
\text { including civil society } \\
\text { organizations and other } \\
\text { stakeholders as stated } \\
\text { in Chapter V of the } \\
\text { ASEAN Charter }\end{array}$ & & \\
\hline $\begin{array}{l}\text { Strive for shared } \\
\text { approaches and } \\
\text { positions on hu- } \\
\text { man rights issues } \\
\text { that become } \\
\text { the interests of } \\
\text { ASEAN }\end{array}$ & $\begin{array}{l}\text { Consult, if necessary, } \\
\text { with national, regional } \\
\text { and international } \\
\text { institutions and entities } \\
\text { related to the promo- } \\
\text { tion and protection of } \\
\text { human rights }\end{array}$ & & \\
\hline
\end{tabular}


human rights institution. ${ }^{12}$

Other regional human rights mechanisms, in their formulation, always distinguish between the function of the promotion and protection of human rights. Related to the protection function, in general regional human rights mechanisms are primarily quasi-judicial, ${ }^{13}$ guarantee the protection of human rights by receiving, analyzing and investigating complaints from the state and other sources, including individuals and conducting on-site visits.

The AICHR ToR also stipulates the composition of the AICHR which consists of representatives from ASEAN member states officially appointed by the governments of ASEAN member states..$^{14}$ In appointing representatives, each ASEAN member state was asked to consider gender equality and the integrity and competence of the prospective representatives. Once elected, the state representative for the AICHR will serve for three years and can only be reappointed for only the next period. During his term of office, representatives will be given immunity and special rights needed in the context of carrying out the duties of the AICHR.

In carrying out its work, the AICHR must be guided by the principles of respecting independence, sovereignty, equality, territorial integrity and non-interference of the internal affairs of ASEAN member states. These principles actually do not align with international human rights standards as outlined in the Universal Declaration of Human Rights (UDHR), the Vienna Declaration that AICHR should adopt in its framework such as 'universality, indivisibility, interdepen-

12 See Kanis Dursin, "ASEAN Rights Body Sorely Lacks of Teeth”, at http:/ / www.aseannews.net/asean-rights-body-sorely-lacks-teeth-critics/, accessed in October 30, 2018.

13 At Inter-America and Africa, the mechanism established to carry out the mandate to promote and protect human rights is not limited to quasi-judicial bodies, but also includes judicial bodies, namely regional human rights courts. In contrast, in Europe, a quasi-judicial body formed, namely the European Commission on Human Rights, was abolished in 1998 when the jurisdiction of the European Court of Human Rights was binding on all States.

14 See Art. 5 ToR AICHR. 
dence and interrelatedness of all human rights'. ${ }^{15}$

Based on the AICHR ToR, every decision to be taken by the AICHR must refer to the consensus system as stipulated in Article 20 of the ASEAN Charter. In other words, every decision issued by the AICHR must be unanimous with full approval from all AICHR members. The basic principle of consensus decision making and consultation has a weakness if it is associated with the protection of human rights because it will be interfered with by political elements and national interests of each country so that the goal of human rights protection itself will not be achieved. This condition also makes it difficult for the AICHR if there are urgent urgent matters to be responded by AICHR.

AICHR meets at least twice a year. If needed, the AICHR can also hold additional meetings to discuss priority issues by first getting approval from the governments of ASEAN member states.

In addition, the AICHR can also hold meetings if ordered by the ASEAN Foreign Ministers forum. The limited mandate of AICHR to make the meeting certainly has an impact on the performance and results to be achieved by AICHR. Especially if the planned meeting must first get approval from the governments of each ASEAN member state.

To support all needs and work in carrying out its mandate the AICHR occupies the same secretariat as the ASEAN secretariat in Jakarta. The absence of a separate secretariat for the AICHR has made this institution increasingly independent, effective and can be monitored totally by its "owners", namely the governments of ASEAN member states. Even though the duties and functions of the AICHR should carry out the oversight function of ASEAN including the member countries incorporated in it related to human rights issues.

15 Yuval Ginbar, "Human Rights in ASEAN-Setting Sail or Treading Water", Human Rights Law Review, Vol. 10 (3) September 2010, p. 514. 


\section{Effect of the Function and Mandate of AICHR on the Effectiveness of Compliance with the Human Rights Obligations of ASEAN Member States}

The establishment of the AICHR is not an easy job considering ASEAN member states have varied commitments in addressing the formation of the commission. Myanmar can be regarded as a country with the weakest commitment to upholding and protecting human rights. Meanwhile, Indonesia, Thailand and the Philippines recognize that each of these countries has a strong commitment to upholding and protecting human rights. While Malaysia and Singapore show positions in the middle. Although the fulfillment of citizens' civil rights is often limited, the fulfillment of economic and social rights can be said to be better compared to Indonesia and the Philippines. ${ }^{16}$

The establishment of the AICHR has special and different characteristics when compared to human rights commissions in other regions. First, the establishment of the Human Rights Commission in other regions is based on special and powerful legal instruments such as the American Convention on Human Rights, while the establishment of the AICHR is based solely on one of the principles of the ASEAN Charter so that other regulations that govern mechanism for more technical legal instruments. For this reason, as stated in Article 14 of the ASEAN Charter, the ASEAN Foreign Minister is given a mandate to formulate the AICHR ToR as a reference framework for implementing the AICHR's activities. Second, by looking at the foundation of its formation, the AICHR is not an independent body or commission because the AICHR is formed by the government, where its membership is representative of ASEAN member states so that the AICHR moves to represent the government. This is different from most human rights bodies in other regions that are formed and act on the basis of the capacity of individuals or groups outside the government. Third, related to the AICHR membership, only two state representatives (Indonesia and Thailand) from 10 representa-

16 Fitria "Questioning the Prospect of Upholding Human Rights in Southeast Asia in the Coming Five Years", in Postscript, Vol. VI, No.5, 2009. 
tives of ASEAN member states were appointed through open and public elections. Representatives from other ASEAN member states are directly appointed by their respective governments.

As stated in the AICHR ToR paragraph 5.2, the AICHR membership is a representative of each ASEAN member designated by the government. The existence of the AICHR is a significant step for the beginning of the common perception of each ASEAN member on the enforcement of human rights in the Southeast Asia region. ${ }^{17}$

From the limitations of its mandate, function and mandate, it can be generally said that the contribution of AICHR to the protection of human rights in the region is limited to dissemination, coordination and consultation of human rights, but has not reached the stage of legal protection. The AICHR is considered only capable of pushing human rights issues to the attention of every ASEAN member states and becoming a joint political agenda for ASEAN. This situation is particularly affected by the political will of fulfilling very diverse human rights obligations in the ASEAN Declaration on Human Rights and the ASEAN Charter itself. Besides the weak political commitment of ASEAN members towards efforts to promote and protect human rights. ASEAN member states have different perspectives on building effective mechanisms for the promotion and protection of human rights. They also still adhere to the "sanctity of state sovereignty" doctrine, so that they place the principle of non-intervention, as a principle that is so important and sacred in the AICHR ToR. ${ }^{18}$

The role of AICHR which is currently limited to promoting human rights is also questionable about its effectiveness. This is because the nature of the promotion of human rights cannot punish the perpetrators of crimes against humanity and other gross human rights violations in the ASEAN region. It is feared that the AICHR will only become an ASEAN formality institution that is engaged in promoting human rights. Therefore, in order to streamline the work

17 Inggrid Galuh Mustikawati, op. cit., pp. 22-23.

18 Wahyudi Jafar, Ardimanto Putra \&Hilman Handoni, "Laporan Penelitian Memperkuat Perlindungan Hak Asasi Manusia di ASEAN”, INFID and ICCO, 2014, p. 34. 
of the AICHR, there must be a body that can prosecute perpetrators of crimes against humanity and human rights violators in the ASEAN region, because the ASEAN Charter and the AICHR ToR are not explicitly regulated to exclude the state when there are sgross human rights violations in the state.

The above situation is illustrated, for example, by Singapore's emphasis which states that the fulfillment of such international obligations must not conflict with its constitution. While Malaysia and Brunei Darussalam determine that fulfilling these international obligations must not conflict with Islam and its national law. The particularistic approach to the norms and mechanisms of human rights by the state becomes an obstacle to the work of the AICHR which is full of legal conflicts. In addition, the AICHR is still focusing its work on developing thematic advocacy activities through certain themes that are prominent in the Southeast Asia region and have not focused their work according to the norms and mechanisms of human rights protection that have existed at international and regional levels, as has been done in the region. Europe and Latin America. ${ }^{19}$

Of the ten ASEAN member states, practically only Indonesia, Thailand and the Philippines can be categorized as states that have a "rights culture" in the basic form, both at the level of government and society, which is reflected in efforts to harmonize with international human rights standards, especially within the framework of the United Nations. ${ }^{20}$ The experience of the three states in the struggle against an autocratic regime and producing democratic governance is what fosters this "rights culture". Meanwhile, Malaysia and Singapore, which have had the same government since independence, have shown a tentative posture on human rights. Nonetheless, priorities in socio-economic development lead to the vigilance of bothstatees on human rights issues that can disrupt these priorities. ${ }^{21}$ Five other

19 Ibid.

20 Tan Hsien-Li, The ASEAN Intergovernmental Commission on Human Rights: Institutionalising Human Rights in Southeast Asia, Cambridge University Press, 2011, p. 136.

21 Ibid. 
ASEAN members - Brunei, Cambodia, Laos, Myanmar and Vietnam - who have a tighter political system can be said to be less emphasis on the international human rights regime.

Another weakness of the ASEAN human rights system and mechanism is the differing views on the form and type of sanctions that will be imposed on the offending state. ${ }^{22}$ In fact, some of the conventions that have been formulated by ASEAN member states have returned raw due to the complicated problems regarding human rights violations. Weak commitment can be referred to the issue of Myanmar which is the most problematic country with the protection of human rights in the Southeast Asia region in recent times. In fact, regarding this matter, former UN Secretary General, Kofi Annan, once urged ASEAN countries to change their foreign political orientation which "does not interfere with members' internal affairs" (non-interference), which was stated in connection with Aung San Suu Kyi's case in Myanmar in 2007. But until now the active role of ASEAN member states has not been seen and prefers to be independent, but still appeals and not through an active role. This also confirms that it turns out that ASEAN countries still adhere to the principle of self-determination.

The implementation of the human rights mechanism in ASEAN member states specifically that is independent to determine their own destiny is motivated by factors of historical similarity in the era of colonialism. All ASEAN members, except Thailand, have been colonized by Western imperialism. As a result of states having the same problem, the solidarity that exists is only limited to immaterial solidarity, not an active action, for example, when Myanmar is hit by political problems, when the military junta arrested Aung San Suu Kyi other states only gave reactions and statements Similarly, when Indonesia was hit by riots in May 1998, other states also did not react excessively, only to the extent of being concerned. In the end this reality formed a common perception to advance human rights within the internal scope of the country because most of the implementa-

22 VOA News, in Pranoto Iskandar, Hukum HAM Internasional: Sebuah Pengantar Kontekstual, IMR Press, Cianjur, 2010, p. 786. 
tion of human rights in ASEAN member states had a close relationship with the constitutional system.

In dealing with the problem of intervention in which no organization or country in the world is separated from western monitoring, ASEAN member states respond to this by accepting and rejecting, meaning that Western pressures are responded to by ASEAN members with gradual adjustments. This is to achieve the suitability of human rights mechanisms in ASEAN member statess with international provisions. The ASEAN Declaration of Human Rights is a political statement from ASEAN leaders. This point is a very big capital for Indonesia to continue to demand that the first review to be conducted in the next five years is to strengthen the protection functions of AICHR which do not yet have the power to discuss the human rights situation of member states.

\section{Conclusion Remark}

The scope of the functions and mandate of the AICHR does not show a balance between the promotion function and the protection function provided by ASEAN to the AICHR to promote human rights in ASEAN. This is more or less influenced by the ambiguity in establishing ASEAN human rights standards, which is on the one hand attempting to meet universally applicable human rights standards, but on the other hand is particularistic by maintaining the "Asian values" view and the principle of non-interference. Thus the AICHR cannot be aligned with other regional human rights bodies such as in Europe, Latin America and in Africa which have a wider and more effective range of protection functions than AICHR.

By itself, the effectiveness of fulfilling the human rights obligations of ASEAN member states is affected by the conditions above. The lack of similarity of views on human rights standards has led to the variation in the fulfillment of human rights obligations by ASEAN membersbecause of the reasons for "certain specificities" and "historical reasons". 


\section{Bibliography}

Dursin, Kanis, "ASEAN Rights Body Sorely Lacks of Teeth", at http: / / www.aseannews.net/ asean-rights-body-sorely-lacksteeth-critics/, accessed in October 30, 2018.

Eberhard, Ronald, "The ASEAN Approach to Human Rights", The Jakarta Post, December 6, 2012.

Fitria "Questioning the Prospect of Upholding Human Rights in Southeast Asia in the Coming Five Years", in Postscript, Vol. VI, No.5, 2009.

Ginbar, Yuval, "Human Rights in ASEAN-Setting Sail or Treading Water”, Human Rights Law Review, Vol. 10 (3) September 2010. Hsien-Li, Tan, The ASEAN Intergovernmental Commission on Human Rights: Institutionalising Human Rights in Southeast Asia, Cambridge University Press, 2011.

Hsiung J.C. (ed.), Twenty-First Century World Order and the Asia Pacific: Value, Change, Exigencies, and Power Realignment, Palgrave Macmillan, New York, 2001

Iskandar, Pranoto, Hukum HAM Internasional: Sebuah Pengantar Kontekstual, IMR Press, Cianjur, 2010.

Jafar, Wahyudi, Ardimanto Putra \& Hilman Handoni, "Laporan Penelitian Memperkuat Perlindungan Hak Asasi Manusia di ASEAN", INFID and ICCO.

Kompas, "Badan HAM ASEAN Jauh di Bawah Standar", at http:/ / internasional.kompas.com/ read/2009/08/09/06163052/badan.ham.asean.jauh.di.bawah.standar, accessed in October 30 , 2018.

Mustikawati, Inggrid Galuh, "Perjalanan Penegakan HAM di ASEAN dan Peran Indonesia Dalam Mendukung Keberlanjutan AICHR”, Jurnal Demokrasi dan HAM, Vol. 9, No. 1, 2011. 